\title{
DigitalCommons@NYLS
}

Articles \& Chapters

Faculty Scholarship

2004

Rights in the Shadow of Class: Poverty, Welfare, and the Law

Frank W. Munger

Follow this and additional works at: https://digitalcommons.nyls.edu/fac_articles_chapters

Part of the Law and Economics Commons 


\title{
18
}

\section{Rights in the Shadow of Class: Poverty, Welfare, and the Law}

\author{
Frank MUNGER
}

Persistent poverty is a source of conspicuous failure in developed economies such as the United States, which boasts of its affluence and vigorously advocates free labor markets, laissez faire capitalism, and law around the globe. To many, it seems selfevident that the extremes of wealth and power created by a capitalist economy and free labor market will result in unequal justice for rich and poor. Documenting and explaining the legal inequities experienced by poor people has appealed to the critical impulse of sociolegal scholars who perceive the treatment of those who live in poverty as an important example of flaws in the law's promise of equal justice.

Sociolegal research on the legal experiences of the poor reflects an understanding of the close connection between economic inequality and law. Yet economic inequality has always created a dilemma for sociolegal scholars. Early sociolegal research was embedded in the values of liberal legalism and the perspectives of American social science. Although sociolegal scholarship is often critical of liberal legalism, it has been strongly influenced by it. Liberal legalism accepts the legitimacy of economic inequality and simultaneously maintains that equal justice is achievable. Because economic inequality is morally acceptable there is a presumption that legal inequities are transient, that law can be insulated from social differences, and, at the same time, that many policies creating or preserving economic differences are legitimate. As a result, injustice caused by morally condemned extremes of poverty has been an easier target for sociolegal scholars than class inequalities sustaining the economic core of capitalism.

Further, American social science was shaped from its early stages by the pragmatism of the Chicago School, which turned away from European social theories of class according to which poverty and class conflict are inevitable by-products of unregulated capitalism (Simon, 1999). Chicago School sociology embraced a perspective more consistent with the faith that America is a "classless" society, conceiving of poverty as a product of transient social disorganization, dysfunction, and individual failure, while the forces of the market were considered an inevitable, 
indeed foundational, aspect of American society. Alice O'Connor's (2001) perceptive history identifies this perspective as a problem at the core of "poverty knowledge." Poverty scholars have persistently focused on the capacities and competitiveness of the poor. When they have also considered the political and institutional sources of poverty they have failed to develop an effective counterperspective to the popular political discourse about the poor's moral failure and individual accountability; to the contrary they have reinforced that perspective by the amount of time and attention they have devoted to it, making it more complex and nuanced, but never effectively contesting its legitimacy.

If sociolegal studies have been swept along by the tide of development in American social science (Sarat and Simon, 2001; Simon, 1999), they have also kept alive a critical perspective, growing from legal realism's critique of liberal legalism's claims and strengthened by the contributions of the critical legal studies movement. Research blends different, sometimes inconsistent, explanations of the relationship between poverty and law. Some scholars, like O'Connor, perceive that poverty springs from the relationship between those who benefit from a competitive labor market and a capitalist economy and those who inevitably suffer (see Wright, 1994). According to this relational perspective, poverty arises from systemic sources, and poverty relief inevitably creates conflict between groups with different economic and political interests. Few sociolegal studies actually pursue the implications of this perspective. More frequently, a second perspective prevails, which foçuses on differences between the poor and the mainstream. This approach emphasizes how law matters to poor individuals - how poor persons' perceptions of law, legal capacities, and experiences of law and legal culture are different from those of other persons. While research from an individual perspective may illuminate the shortcomings of liberal legalism, research must adopt a relational perspective to explore the law's role in poverty's persistence, welfare's failure, and the promise of rights.

This chapter describes three approaches to research on poverty and law that blend these contrasting perspectives. During the civil rights era of the 1960s and 1970s, sociolegal research on poverty focused on the failure of law's promise of equal justice for the poor. A second type of research, evolving out of the first, examines how law matters from the perspective of the poor. This research has studied, in particular, the "legal consciousness" of poor persons that illuminates practices of legal domination and resistance in everyday life. Contemporary scholars increasingly pursue a third approach that examines welfare state politics and administration. Through this approach, scholars are examining whether law assists in the realization of power and privilege for some through welfare state institutions that create poverty and dependency for others.

Critical examination of the relationship between law, poverty, and the welfare state has had little effect on policy makers. Why should that concern us? Some have suggested that sociolegal studies should ignore the "pull of the policy audience" (Sarat and Silbey, 1988). But many poverty scholars believe that turning away from power holders defeats what they believe to be a central purpose of their work (see Ewick, Kagan, and Sarat, 1999; Handler, 1992; Gilliom, 2001). Scholars face the challenge of conducting research that will deepen the understanding of citizens and policy makers without allowing the myths, stereotypes, and misconceptions created by the politics of public discourse on the poor to narrow their vision. This chapter concludes by describing two difficult issues confronting scholars who hope to change policies that oppress and exclude poor persons - race and political power. Race, 
Blumberg, similarly, explains his research by drawing into question the impact of recent legal decisions that protected the rights of criminal defendants. Yet the insight he derives from his study of defenders' interactions with prosecutors and judges is not limited to the formal defects in implementation of legal norms. He describes in some detail the process by which interactions with other participants coopt the role of defense attorneys and influence their relationships with clients.

Both studies contain the seeds of future trends in sociolegal research on the "legal consciousness" of poor persons, the influence of context, and the social interests that compete with the law's formal assumptions about the goals of legal process. Both bring into focus the importance of the participants themselves - the competence, resources, and dispositions they bring to the process. With respect to the latter, Carlin et al. offered an extended analysis of the "legal competence" of the poor litigant.

Levine and Preston (1970) surveyed poor persons concerning their "resource orientation" - the likelihood that they would make use of an attorney to resolve a dispute. The survey showed overwhelmingly that the poor lacked knowledge of their rights and of the availability of legal services lawyers. Those poor who had knowledge often believed they would lose, a belief that discouraged them from contacting a lawyer. Likewise, Felstiner's (1974) analysis of dispute behavior concluded that the poor are far more likely to "lump" than litigate their grievances. Levine and Preston also showed that there was considerable variation in knowledge, but a "positive" resource orientation was concentrated among younger, white, poor persons.

Studies on which Carlin et al. drew in their analysis viewed the poor as a particularly unfortunate and vulnerable group that was frequently victimized (see Caplovitz, 1963 who studied unethical dealing with poor consumers; Wald, 1965 reporting oppressive treatment of welfare recipients by creditors in the automobile market; Note, 1965 describing lax code enforcement in low-rent housing). Victimization followed from the poor's lack of market alternatives, lack of political power, consignment to less rights-oriented legal forums, and lack of knowledge and resources to contest wrongful treatment. In each of these ways, the poor were depicted as different from the mainstream and unable to protect themselves. The failure of law to protect the poor drew both legal and sociolegal scholars to examine the roles played by attorneys who represented the poor (see Carlin, 1962; Carlin and Howard, 1965; O’Gorman, 1963; Katz, 1978; Abel, 1979; Handler, Hollingsworth, and Erlanger, 1978).

Some of O'Connor's criticisms of American poverty research apply to these civil rights era studies of poverty and law. Carlin and his coauthors studied only the poor; for them, the term "class" has no particularly political or relational meaning. Blumberg made no comparisons between rich and poor (still less between social classes), though the ability of defense attorneys to conduct a "confidence game" may have depended in significant part on the class differences among the participants he describes (e.g., clients versus attorneys, public defenders versus attorneys in whitecollar civil or criminal matters). The inevitable link between poor clients and criminal justice is too obvious for comment. Although civil rights era research did more than document the limits of liberal legal justice, it seldom explored the origins of poverty, the politics underlying policies, or whether the economic inequality was created or sustained by law.

The studies ignored an important tradition of research on African American poverty that probed the sources of poverty and placed lives in context, including 
interactions with authorities (DuBois, 1899; Frazier, 1939; Liebow, 1967; Stack, 1976; Ladner, 1971). Further, scholars emphasized the unique characteristics of poor individuals, not the causes of their social circumstances. Criminal justice scholars, who studied the legal processes most involved with the poor, seldom gave critical attention to individuals' poverty or class (contrast Chambliss, 1964 and Hagan, 1994). Conceptualizing poverty in relational terms might have led to different questions: whether the disadvantages experienced by some are sustained by benefits they confer on others, and, in particular, who is advantaged by the particular kind of competence required by the legal system?

Finally, this research offered a limited view of legal process. Reich's arguments about the importance of entitlements were widely discussed but little sociolegal research pursued their implications for the poor. Poor persons encounter administrative decision makers relatively more frequently (Mayhew and Reiss, 1969) and are more likely to face informal but coercive administrative decision making than wealthier citizens (Lipsky, 1984). When poverty programs moved off the scene in the 1970 s and 1980s, sociolegal poverty research all but disappeared.

Galanter's (1974) seminal essay, "Why the 'haves' come out ahead" took stock of the critique of liberal legalism's promise to "have nots." The overwhelming evidence of bias against "have nots" showed that the capacity of the law to bring about social change was limited by the very social factors that formal changes in the law were intended to neutralize. Galanter's synthesis is powerful because the legal system's bias was not limited to subordinate persons such as the incompetent poor but worked against other individuals as well whose lack of experience and resources disadvantage them. But Galanter's synthesis focused, like much mainstream poverty research, on the competitive disadvantages of individuals. Differences in litigants' legal competence, together with the legal system's inherent inability to alter the effects of this social inequality, create legal bias. Because his essay focuses on legal process rather than social relationships, Galanter did not explore the legal bases for class privilege or power, but limited his discussion to the process by which those with power use law to their advantage.

"Haves" is a summation but also a turning point that can be readily marked in research on poverty. Scholars were already moving away from a self-contained view of legal process. Legal process was not passive and reactive. Law and its context were interactive, and law helped to constitute the social relations that led to legal inequality. Increasingly sophisticated studies showed the varieties of legal experience of individuals in different social roles, contexts, and backgrounds, problematizing the very concept of legal equality (Mayhew and Reiss, 1969; Moore, 1974; and Felstiner, Abel, and Sarat, 1980). These trends suggested to many scholars that analysis of the relationship between social hierarchy and legal inequality should be studied from a more subjective perspective and in the varied contexts of everyday experience.

\section{How Law Matters for the Poor - Legal Consciousness, Domination, Resistance}

Poverty research of the civil rights era was transformed by the collapse of the War on Poverty. A conservative backlash against civil rights and poverty rights, termination or cutback of many poverty programs, and racial politics made the work of proges- 
sive and critical poverty scholars unwelcome among policy makers and discouraged new research projects. Since the 1970 s, government-sponsored poverty research has been carefully limited to program evaluation and impact studies, narrowly focused on incremental program goals (Katz, 1989).

For scholars outside the narrowing mainstream of government-sponsored poverty research, a critical perspective on poverty was maintained within an evolving field of sociolegal research. An important shift in perspective marked this evolution. The new trope - law in context - focused on the disjunction between formal law and law's role in context - law in everyday life. Greater attention was given to the law's noninstrumental roles in everyday life - symbolic, contested, and constitutive. The new perspective made the interpretations of ordinary persons central to understanding the meaning and effects of law. Ordinary persons interpreted and gave meaning to law at sites of everyday interaction and contention such as families, neighborhoods, and workplaces as well as in lawyers' offices and courts.

Studying law in everyday life provided an important new window on inequality and domination, and "legal consciousness" became a focus of such studies. The poor, women, African Americans, were no longer simply categories of litigants. Law shaped their consciousness as individuals and citizens and thus influenced their routines and interactions in everyday life. The poor and oppressed, as legal actors, acquired agency both as individuals and as actors within systems of culture and meaning through the development of their legal consciousness. Indeed, the emphasis on agency became a defining element of critical research on law, which claimed to give voice to the "other" - a voice that had previously been lost in the larger picture of liberal legalism and legal process (Silbey and Sarat, 1987).

Three influential studies illustrate this pursuit. Ewick and Silbey (1992) describe the legal consciousness of "Millie," a poor black domestic housekeeper charged with a hit and run accident involving her uninsured car while it was being driven by a friend of a relative without her permission. Austin Sarat describes the legal consciousness of the "welfare poor," who seek assistance from legal services attorneys, concluding that it is "substantially different from other groups in society for whom law is a less immediate and visible presence" (1990: 344). Lucie White (1990) studies the welfare hearing of "Mrs. G.," examining the culture and history that shapes subordination. She suggests that the law seamlessly reinforces the inequalities experienced by her client throughout her life and creates a consciousness of humiliation - as a morally stigmatized recipient, intimidation - because her voice is silenced in welfare proceedings, and objectification - displacement of her true needs by bureaucratic definitions of "needs" and "entitlements."

The concept of legal consciousness has had an important influence on studies of law and poverty, for example, research on legal process (Mahoney, 1991; Alfieri, 1993), the attorney-client relationship (Alfieri, 1991, 2001; Davis, 1993; Harris, 1999; Lopez, 1992; Trubek, 1994; White, 1988; Sarat and Felstiner, 1995; for critique see Simon, 1996), and the impact of specific welfare laws (see below).

Perhaps the most profound and controversial influence, however, has been on the way scholars perceive the distributive impact of law, for above all these studies suggest that the subtle influence of legal consciousness on legal process and legal rights explains - one more time - why the "haves" come out ahead. Engel (1998) criticizes these studies for conceptualizing the legal consciousness of the poor categorically. Legal consciousness, he argues, is treated as a collective mindset reproduced by law rather than the end product of an interactive and intersubjective 
process that shapes each individual's consciousness. For Ewick and Silbey, Sarat, and White, the agency of subordinate persons in such settings is resistance and "tactical." Engel also suggests that legal consciousness research has overlooked insights long established in the sociolegal field - potential variation in legal consciousness over different substantive areas of law, the multicentered relationship between law and society, and the mediation of unofficial systems of rules and meanings.

\section{The problem of agency}

At stake in the analysis of the law's role in power and resistance is the capacity of the poor for self-help and for political struggle. Critics McCann and March (1996) argue that scholars have been too quick to declare poor persons independent and autonomous actors on the basis of isolated acts of disobedience or circumvention of the law. Progressive scholars believe change from the bottom up is necessary for lasting democratic and egalitarian reform, and they resist the image of subordinate persons as passive, apathetic, or possessing false beliefs in the legitimacy of oppressive authority. But misjudging the autonomy of the poor can have negative consequences, Handler (2002) argues, because the image of the poor as willful and capable accords well with the arguments of conservatives and the moral politics of welfare that blame the poor for their poverty.

McCann and March find that three justifications for the significance of such "little events" are suggested by the studies themselves. The first is that the studies map "oppositional consciousness," debunking the theory that subordinate persons possess a false consciousness of the "myth of rights." These findings are similar to those of a long line of Marxist social historians (Hay, 1975; Thompson, 1975; Genovese, 1976).

Second, small acts of resistance may be "significant in a psychological, or existential sense" because they affirm "basic dignity, autonomy, and personhood" (McCann and March, 1996: 226). But McCann and March are deeply skeptical about such claims, concluding that "many of these works could be read as sorry accounts of experiences that only deepen the sense of what John Gaventa (1980) calls 'powerlessness' among marginalized citizens" (McCann and March, 1996: 227; cf. Roberts, 2000), and studies confirm his conclusion (White, 1993; Soss, 1999).

Handler $(1996,2002)$ argues that isolated acts of resistance can be empowering only as part of a developmental process, such as that described in White's (2002, and in preparation) study of mothers in a Head Start program. Similarly, Gilliom's (2001) interviews with poor Appalachian women about welfare surveillance suggested to him that everyday acts of resistance could "work as forms of politics" where particular conditions were met - tangible improvements, sharing and collaboration among participants, and "ethical grounding or ideology within which to frame resistant practices" (Gilliom, 2001: 103). Gilliom found the women countered control by embracing an ethic of care that elevated commitments to others over compliance with welfare regulations.

A third justification for studying everyday acts of resistance is their potential for political escalation. Yet most studies of law and everyday resistance have focused on the actions of isolated individuals, with little examination of their relationships to group identity or support, making them unlikely candidates for collective political action. Context is critical for the political potential of law. Understanding the politics of power and resistance requires a frame of reference that indicates what 
is at stake and what is gained or lost in particular encounters between dominant and subordinate persons, that is, a relational framework of understanding. Moreover, resistance with the potential to escalate politically is about broad struggles - against racism, economic exploitation, or patriarchal control - and not merely tactical maneuvering against judges, clerks, administrators or other officials (McCann and March, 1996: 220; cf. Handler, 1992). In brief, scholars studying the legal consciousness of poor persons must pay more attention to the social organization and institutional context underlying domination and resistance.

\section{Welfare State Administration - DEPENDENCY BY LAW}

Contemporary scholars recognize the continuing but contingent role of state power in creating and maintaining poverty, and many are also interested in reconstituting the welfare state - a search for an affirmative and more democratic welfare state (Garland, 2001; Sarat and Simon, 2001; Handler and Hasenfeld, 1997). The American welfare state's long history of stigmatizing and inadequate assistance for the poor might well make us doubt whether truly affirmative programs will be adopted without substantial political change. Both civil rights era impact research and studies of legal consciousness suggest that the poor will often be among the most oppressed and the least capable of politically altering this familiar pattern.

Sociolegal scholars have been energized not only by frustration with their declining influence in an era of "cultural politics" (Simon, 1999; Garth and Sterling, 1998), but also by concern about the effects of welfare state retrenchment on minorities, immigrants, workers, women, and the poor. Global crises connecting First and Third World economies have always enhanced the critical understanding of sociolegal scholars, and some poverty scholars have explored this connection in their research (e.g., Handler, 2003; Coombe, 1995; Santos, 1995; White, 1998; Nightingale, 2002).

\section{Critical scholarship - race, gender, class, in the welfare state}

If, as McCann and March claim, research on legal consciousness of the poor requires a relational and political perspective, critical race and critical feminist scholars have played an important role not only by developing a relational perspective on poor women and minorities, but also by addressing the issue of political voice. Critical feminist and critical race scholars were among the first to place legal domination of poor women and minorities in historical and institutional context and, in this context, to explore the role of emancipatory practices capable of undermining legal domination.

Critical histories of the evolution of poverty and welfare set the stage for sociolegal research on contemporary welfare state policy and its administration. Although a generation of progressive scholars of working-class conflict examined the role of law in class domination and politics (Piven and Cloward, 1971; Hay, 1975; Thompson, 1975), Gordon (1988b) criticized them for ignoring the evolving nature of poverty, in particular its concentration among minorities and women, groups never assimilated into the primary labor market and unlikely to participate in the class struggles envisioned by nineteenth-century theorists (see also Quadagno, 1992). Critical feminist and critical race historians (Gordon, 1988a, 1994; Quadagno, 1994; Sterett, 
1997; Skocpol, 1992) have transformed our understanding by showing that patriarchy and racism have molded the character of the American system of public relief. Fraser and Gordon (1994) trace the cultural shifts in the concept of "dependency" that prefigured (and were reinforced by) these welfare policies. Dependency carries taken-for-granted connotations that limit the discourse about welfare, especially assumptions about "human nature, gender roles, the causes of poverty, the nature of citizenship, the sources of entitlement, and what counts as work and as a contribution to society" (Fraser and Gordon, 1994: 311).

Significantly, critical race and feminist scholars place the identities and consciousness of poor persons in a concrete historical and relational context. They have demonstrated that a relational view of inequality was essential -inequality continues because of the support for institutions that maintain patriarchy and white privilege.

Further, critical scholars emphasize the importance of variations in context and perspective in determining the role that rights play in the lives of weak and powerless persons. While rights often constituted domination of the oppressed, historical examples showed that they could also be turned to the advantage of subordinate persons under circumstances that permitted their movements to gain power (Crenshaw, 1988; Schneider, 1986; see also Piven and Cloward, 1977). The role of rights, they argued, also depended on voice and perspective. Minow's (1990) analysis of contemporary and historical examples showed that the law may promote inclusion and full citizenship when the experiences of those who have experienced poverty and oppression influence legislative, administrative, or judicial processes. Conversely, she traces the counterintuitive stigmatizing effects of many civil rights laws to their origin in the consciousness of legislators, judges, and professionals who lack a complete understanding of the ways that society creates the disadvantages encountered by the oppressed.

Finally, critical scholars' sensitivity to voice has caused them to raise important questions about studies of domination and oppression - how can scholars "know" the experiences of socially oppressed groups and interpret or "give voice" to their concerns (see Minow, 1990: 195-8; cf. Sarat, 1990; White, 1990)? The importance of the poor's own voice in the realization of rights suggests to some scholars that the poor must play a central role in the research enterprise itself, shaping issues, gathering and interpreting data, and discovering ways to deploy rights for change (Ansley, 2002).

Critical scholarship on poverty and the welfare state, like studies of legal consciousness and law in everyday life, have strengthened the growing perception among poverty scholars that the poor are active rather than apathetic and have experiences and values as varied as the mainstream. Scholars have begun to shift their attention to understanding how the poor "navigate the welfare state from below" (Katz, personal communication, 1997). The question is, what have scholars learned about the welfare state and how does that enrich their research on poverty and law?

\section{Moral citizenship}

Critical history of poverty law shows that fundamental economic conflicts that divide society along lines of class, gender, and race underlie welfare state policies: the desire of employers and the well-to-do to preserve the advantages they derive from the market versus the desire of workers, working poor, unemployed caretakers 
and others unable to obtain a living wage job for greater economic security (Katz, 1986, 1989; Handler and Hasenfeld, 1991; Fraser and Gordon, 1994). Why do these economic conflicts rarely emerge in public discourse?

The history of Anglo-American welfare policy shows that economic interests of groups divided by class, race, and gender have been expressed in a discourse of moral identity and social citizenship (Gordon, 1994; Handler and Hasenfeld, 1991). Eligibility for social provision has never been a universal right, but rather a residual for those deserving poor who cannot support themselves. Sociolegal poverty scholars, among others, have described the important distinction drawn between the deserving poor, who merit social insurance and protection against the hardships of the free labor market, and the undeserving poor, who merit help only in times of severe hardship and under conditions intended to reform their flawed moral character (Katz, 1986, 1989; Handler and Hasenfeld, 1991; Fraser and Gordon, 1994). In this respect, social rights resemble a contract rather than a universal citizenship entitlement (cf. Mead, 1986). Individuals are obligated to make themselves selfsufficient by fulfilling the roles - as wage earner, as wife of a wage earner, as a married parent - that society envisions for them. Those who do not conform are undeserving of welfare (Pearce, 1990; Mink, 1990).

Welfare law plays a different role in other cultures that associate different identities with dependency. Anglo-American culture is representative of societies that Esping-Anderson terms "liberal" welfare regimes," that place "unbounded faith in market sovereignty" (1990, 1999: 81) and offer low level, means-tested welfare benefits designed to reinforce labor market participation (others are Australia, New Zealand, and Canada). Most European countries - such as Austria, France, Germany, and Italy - together with Japan have "conservative" welfare regimes that emphasize preservation of family and social status, for example by providing family benefits sufficient to allow women to remain at home in traditional nonworking roles. Scandinavian countries have "social democratic" welfare regimes that decommodify labor through universal, nonmeans-tested benefits. In theory, the implications of differences between these regimes for the moral identity of welfare recipients are great. Handler (2002) has argued that the regimes are converging in practice due to the growing strength of conservative ideology and to inevitable similarities of bureaucratic behavior. But whether or not there are additional points of similarity or difference, the strong association between historical development, moral discourse, and social provision seems beyond question.

The moral content of the discourse of social citizenship has provided a powerful tool for explaining the details of welfare policy (Gordon, 1988b; Skocpol, 1992; Sterett, 1997), the evolution and impact of social movements for poverty rights (Piven and Cloward, 1977; Handler, 1978), and the role of gender and race in the relationship between poverty lawyers and their clients (Davis, 1993; Lopez, 1992; Alfieri, 1991). Fraser and Gordon (1994) trace the relationship between the changing moral stigma of "dependency" and welfare in the twentieth century. Early programs stigmatized particular women - poor, immigrant, unmarried - but not others, for example the white widow. With the increasing enrollment of unmarried African American women in Aid to Families with Dependent Children (AFDC) in the 1960s, the image of deviant dependency was again a mirror image of white, middle-class normality - now the unmarried female head of an African American household. Disturbed by rising rates of employment among mothers in white families, increasing divorce and declining marriage rates, Americans experienced a 
"moral panic about dependency" in the 1980s (Fraser and Gordon, 1994). Welfare reform in the 1990 s reflects the latest politically inspired image - generations of African American teenage mothers trapped by welfare in a cycle of helpless dependency (see P. Williams, 1991; Roberts, 1997b, 1999).

Above all, Garland (2001) argues, the emphasis of the market on voluntary choice grounds the moral identity assigned to persons. The poor, the unemployed, the unmarried, the underqualified, the discriminated against, the abused who cannot work or cannot earn enough for themselves and their families to survive are presumed to have chosen not to work and to rely on welfare. They are subjected to discipline in exchange for benefits under conditions designed to make them seek work and behave in other ways deemed appropriate for citizenship by achieving selfsufficiency through work or marriage and by discouraging the "moral hazard" of unnecessary reliance on benefits.

A substantial body of scholarship describes policies reflecting welfare mothers' moral identity and ignoring their actual behavior and experiences (Fraser and Gordon, 1994; see also Fineman, 1999; J.A. White, 2000; Roberts, 1997b; McKinnon, 1993; Karst, 1989). Studies of poor women examine the origins and effects of morally stigmatizing welfare policies that inhibit rather than help poor women in performing the labor that society tacitly demands - responsibly caring for families (Gordon, 1994; Edin and Lein, 1997; McClain, 1996; Raphael, 1996; Gilliom, 2001). Some welfare policies, particularly those affecting reproductive rights, have been applied with a marked racial bias and reflect stereotypes that prevailed in the welfare reform discourse of the 1990s about the unfitness of young black women for parenting (Roberts, 1997a). Similarly, state officials have continued to remove a disproportionate number of black children from their mothers and place them in foster care (Roberts, 1999). Scholars describe a mismatch between the images of welfare recipients and their actual lives that turns the public face of assistance and rehabilitation into a less visible reality of inappropriate and punitive effects (L. Williams, 1992).

\section{Myth and ceremony in administration}

One of the most provocative observations in Galanter's (1974) massive mapping of legal process appears almost as an afterthought in a long aside on "appended" dispute resolution systems, including administrative adjudication, mediation, negotiation, and nonlegal dispute resolution. He suggested that resort to appended systems was less about rights and more about restoring relationships, but his characterization ignored precisely the problem of "class" justice. Because the rapidly increasing importance of welfare state entitlements shifted rights disputes from courts to bureaucracies for many citizens but for poor citizens in particular, for the poor, this exception threatened to swallow his paradigm. The relatively poor and powerless, far more than the affluent and powerful, encounter layers of informal administrative decision making respecting important rights.

Because welfare policies are based on moral identity as well as on the needs of the poor, Handler and Hasenfeld (1991) argue that there has always been a wide gap between the rhetoric of poverty policies and the practical administration of welfare. They refer to the gap as the "myth and ceremony" of welfare policy - "myth" because of the discourse of policy making and legislation that relies on stereotypical and contradictory images of the poor, and "ceremony" because difficulties in adminis- 
tering policies that bear little relation to the real needs of poor people typically result in token enforcement for a few recipients and widespread, unacknowledged administrative default for the rest. Policies requiring welfare recipients to work have historically been impossible to enforce because they have ignored the real problems that the labor market creates for those who are poor. For example, in the early 1960 s, the law required social services for recipients but in reality agencies lacked the capacity and had little incentive to provide such services (Handler, 1990). Rising welfare roles due in part to an aggressive welfare rights movement eventually ended ceremonial compliance as formal emphasis shifted to eligibility determination (W. Simon, 1983).

Research suggests that recent welfare reforms will repeat the pattern. Welfare reform has tightened work requirements, imposed lifetime time limits, and added other restrictions that require close supervision and enforcement (Kost and Munger, 1996). Women who are particularly creative in acquiring support from others in a resource-poor environment are more successful in maintaining employment (Henly, 2002) and raising children (Edin and Lein, 1997), but they often must violate specific mandates of the welfare law in order to maintain their families (Gilliom, 2001). Those with multiple barriers to employment - such as lack of education or transportation - or who have a disability (up to 40 percent of the deeply impoverished) cannot work (Danziger et al., 1999). Welfare administrators offer meager assistance in coping with these problems, and yet all recipients face mandatory time limits on welfare. The new law encourages sanctioning recipients for their "voluntary" failure to comply by reducing or ending welfare support without respect to need. Reviewing these and other studies, Handler and Hasenfeld (1997) conclude that the moral images that influence welfare legislation will lead to more myth and ceremony.

The myth that a formal declaration of entitlement to welfare will guarantee benefits has long been discredited by studies showing that administrative practices impeding recipients' efforts to become eligible result in "bureaucratic disentitlement" (Lipsky, 1984; see also Bennett, 1995). Caseworkers, like legislators, are influenced by their "moral typification" of recipients (Hasenfeld, 1983; Brodkin, 1997). The myth that formal policies and due process will guarantee individual autonomy and empowerment has been thoroughly examined and criticized by Simon (1983) and by Handler $(1986,1990)$.

Empowerment of welfare recipients may be even more difficult in the new era of entrepreneurial government and management by objective. Under the new system, welfare caseworkers are given even more discretion to achieve the goals set by supervisors, but Diller (2000) suggests that top-down control continues to be exercised in ways that limit the range of outcomes of client-caseworker interaction, if not the means by which they may be achieved. Serious questions arise about whether liberal legalism can insure that discretion is exercised without arbitrariness or discrimination. How much discretion entrepreneurial government creates in practice, how such discretion will be used, and whether there are effective means of checking abuses are important issues for further research (see, e.g., a rare study of racial bias in welfare by Gooden, 1998).

\section{Welfare as "private government"}

Macaulay's (1986) insightful analysis of "private government" reminds us that social networks, neighborhoods, associations, corporations, contracts and other private relations that "govern" individuals often mediate the effects of public policy and law. 
He reminds us that the law's attempts to set terms for relationships within organizations or between contracting parties rarely counters existing imbalances in power. Macaulay's analysis also encourages looking beyond welfare administration to its impact on the social relationships in the private world of welfare recipients which welfare law ultimately attempts to govern.

Sociolegal scholarship suggests that his insight is particularly applicable to postreform welfare administration where multiple layers of public and private organization interact and mediate in carrying out federal and state mandates. Two concepts laden with market ideology - devolution and privatization - have legitimated giving more control of welfare to state and local governments and permitting private service providers to assume responsibilities for welfare previously assumed by public servants (Katz, 2001). Both concepts suggest that greater efficiency will be achieved - more effective welfare at lower cost. In truth the system of welfare in the USA has always been highly decentralized. States and their subdivisions have administered federally funded welfare since the program's inception and private providers have always played an important role.

States have responded to the devolution of new responsibilities by giving local administrators even more control and by contracting out core welfare administration as well as more specialized services. State and local politics control the level of welfare spending as well as the symbolic emphasis placed on work and supporting services (Cashin, 1999). Reliance on private entrepreneurs to provide administration of welfare depends on a contracting process controlled by administrators beholden to the same political constitutencies who resist spending and restrict welfare (Bezdek, 2001).

Gilliom (2001) has shown that increasingly intrusive welfare surveillance and control of recipients harms welfare recipients' relationships with others and their self-images. The myth of welfare reform is that strict accountability will ultimately strengthen poor women's social capital, but the reality is that such intrusive administration often undermines existing social relationships and impedes investment in new social capital (Edin and Lein, 1997; Stack, 1976). Gilliom's interviewees found that evasion and circumvention of welfare law were necessary for survival of their families but in turn this often unavoidable behavior had harmful effects on their selfimage as moral citizens (Gilliom, 2001; contrast Rothstein, 2001).

Thus there is a risk that decentralization will simply disguise the process of domination of welfare recipients who will not be helped to achieve self-sufficiency and whose failure will confirm the myth of their dependency. Welfare recipients will have become even more dependent by law (Munger, 2002). While some have argued for revival of a stronger welfare state (Lowi, 1998; Karst, 1997), others point to research suggesting that the outcome of devolution and privatization is indeterminate. Handler (1996), for example, describes case studies that show that empowerment can be achieved when the administrative priorities of the powerful are contested politically and also through "empowerment by invitation" when administration creates opportunities for development of self-confidence and participatory competence. He suggests that the latter form of empowerment is possible only when power holders gain something from participation by dependent people, such as stability, profitability, or legitimacy, and when such opportunities continue long enough to allow a sense of efficacy and trust in participation to develop (Handler, 2002). Lucie White's (2002) analysis of mothers' empowerment through participation in a Head Start program illustrates his argument. 
Sociolegal research on the administration of welfare in the welfare state is poised to break new ground by focusing on the complexity of organizational and institutional structures and processes that shape the law's symbolic and constitutive impact. State, local, and private compliance with statutory (and constitutional) welfare law requirements; the spread of welfare program innovations among the states (see, e.g., Soule and Zylan, 1997); symbolic compliance at the institutional level; the "capture" of local programs by their social, political, and economic context - all seem ripe for study. In turn, sociolegal poverty scholars exploring the cultural and symbolic roles of law in the welfare state can benefit from available literatures on the new institutionalism and organizational theory (Suchman and Edelman, 1996; see also Smith, 1988) that address these and similar processes of organizational change and development.

\section{Governing Through Poverty - Two Challenges FOR RESEARCH}

The Russell Sage Foundation (Farley, Danziger, and Holzer, 2000) began its analysis of the relationship between race and poverty in Detroit by asking why blacks and whites live in segregated communities 50 years after racial covenants were declared unconstitutional and 30 years after the Fair Housing Act outlawed racial discrimination in the housing market. The Foundation's sociologists find an answer in public attitudes toward race. They do not comment, as they should, that the law's role has been shaped by the same racial divide, notwithstanding seemingly benign actions of the Supreme Court and Congress (cf. Freeman, 1998). Sociolegal scholars have much to contribute to an understanding of law's complex role in maintaining the welfare state's institutions that divide social classes and exclude many from equal opportunity.

\section{The problem of race}

Lee Rainwater (1970) and Herbert Gans (1969), in separate essays, tried to explain why oppressive poverty policies seemed different and difficult to attack politically. Rainwater guessed that the wretched conditions and insecurity of the poor were threatening to the mainstream, whose security and affluence similarly depend on the contingencies of the labor market. The cognitive dissonance between the mainstream's sense of security and these "betrayers of the American dream" (Murphy, 1987: 116-17; see also Wuthnow, 1996) was relieved by creating an identity for the poor that makes them different - self-indulgent, foolish, improvident, pleasureseeking, or corrupt. Today, in a world of increasingly insecure labor conditions, these characterizations of the mainstream and the poor are no longer merely unselfconscious underpinnings of identity but appear at the forefront of poverty politics that keep an insecure working class allied with employers who are hostile to public and private welfare. Gans always claimed the sources of punitive attitudes toward the poor were much more concrete and visible. The existence of the poor benefits more affluent citizens, taxpayers at large, and government administrators. Stereotypical thinking about the underclass makes it easier to go on enjoying these benefits.

Jonathan Simon (1997) has brought to our attention the increasing importance of the image of the "other" in American governance. Simon has demonstrated that the 
growing divisions among racial groups and between rich and poor have greatly altered our expectations for and practices of governance. The fact that such divisions are marked by differences in culture and political perspective makes consensus, negotiation, and reconciliation of conflicts among the interests of these groups difficult. Simon argues that an image of the criminal "other"- a person of color, poor, predatory, and urban - drives a wide range of public policies of containment, separation, statistically based crime prevention, and punishment that affect not only criminal justice but also land use, transportation, public funding of schools, national electoral politics, and other major institutional arenas.

Poverty, like crime, is also a means of governance. Welfare recipients, like criminals, are stereotyped, reinforcing an image of an "other" whose morally undeserving behavior explains and motivates policies of redistribution and regulation. Welfare dependency is perceived to be a pervasive moral threat, a fear legitimated by the stereotypical identities attached to welfare mothers. Patricia Williams (1991) asks what could possibly justify the shocking murder of a welfare mother in her apartment by fully armed police for "resisting eviction?" Roberts (1997a) describes "genocide" through family planning programs whose racially disparate practices have a significant impact on reproduction among poor black women. Images of the unmarried teenage black woman render the public unsympathetic to welfare recipients and favorable to punitive conditions and harsh sanctions (L. Williams, 1995). Like crime, welfare - and the racial stereotypes that sustain it - help constitute the relationship between social hierarchy and social order.

To conduct more relevant and effective research on poverty, scholars must acknowledge the deep racial fault line in American society and its effects on the identity, self-concept, and behavior of the poor. Race is nearly invisible in mainstream policy research on poverty, and this despite an incontrovertible reality: not only are the experiences of persons of color who are poor different, but different at least in part because persons of color are perceived and treated differently. Martin Gilens (1999) observes a fundamental premise - unexamined in most research on poverty - of the public perception of welfare in the United States: welfare (much like crime) is a province populated by African Americans.

Scholars who want to understand poverty and the public policy debates that surround it must grapple with race-coded discourse. Euphemisms such as "the underclass," "welfare poor," and "cycle of poverty" may sanitize language, but they cannot mask our racialized perceptions of poverty. Nor can they mask the continuing processes of cultural and institutional separation that isolate African Americans from the mainstream. Our race-coded discourse about poverty divides the poor and working classes into two groups: whites who suffer the effects of declining wages, benefits, and job security and therefore are deserving; and blacks who a priori are stigmatized as potential welfare recipients and therefore are undeserving. Until this divide is bridged, Gilens suggests, little will change in the symbolic politics of poverty.

Our concerns about the deep divide between blacks and whites in America, as well as the persistence of patriarchal values, should lead us to a more profound understanding of the stakes in the economic order that fuel them (see insightful criticism by J. Williams, 1999; Roberts, 1997b). The division created by race is ultimately part of a larger and more complex story of race, gender, and class, as Jonathan Simon suggests, which greatly complicates the identities of the poor but also creates a broader potential for political change. 


\section{The problem of politics}

Underlying the moral politics, welfare in all its forms has served dominant economic interests, especially their interest in stabilizing the supply of labor. Katz (2001) describes the relationship among the American welfare state's three sectors - public, independent (not-for-profit), and private. The private sector consists primarily of employee pension and medical care, together with mixed public-private welfare such as unemployment and workers compensation programs. One reason that the stigma attaching to public welfare programs has remained difficult to change is the political split between segments of the working class created by the mix of public and private welfare - workers dependent upon private, contributory welfare are opposed to being taxed a second time to support public welfare for still poorer, and typically minority, unemployed persons (see Noble, 1997). Some political movements by poor people have been sufficiently destabilizing in domestic politics to influence the passage of more favorable legislation (Piven and Cloward, 1971). More often, carefully limited liberalization of public welfare, for example during the New Deal, has been supported by larger employers interested in labor market stability.

Contemporary welfare reform is just one of many related changes in public and private governance that is supported by stereotyping groups, that dominant economic interests want to control (Garland, 2001). The attack on "dependency" has included downsizing workers compensation, reducing worker security and representation, restricting consumer access to bankruptcy, limiting relief to unemployed and displaced workers, and contention over health insurance reform (see McCluskey, 1999; Katz, 2001). Workers' benefits not related to the bottom line are characterized as a form of economic fat, privilege, and immoral dependency, the mirror image of efficient, market-driven, and, therefore, "fair" labor policy. All of these active interventions by the state to reregulate the labor market enable employers to pursue low wage and flexible labor strategies to increase profitability.

The assault on dependency thus creates a potential basis for broad political coalition. Still more broadly, as Gilliom (2001) has suggested, the common experience of welfare state surveillance and control of citizens may provide an even wider source of shared understanding and political action.

When law fails in its promise to become an effective enabling force for protecting equal rights in the welfare state, we are left with "the long walk home... to politics" (Simon, 1992). The question is how to think about welfare politics. This final task for law and society scholars has already been begun by examining the mutually constitutive role of identity, welfare policies, and the practices of governance. Recent law and society studies examine the effects of enacted law on everyday lives of marginal and excluded persons (Engel and Munger, forthcoming; Munger, 2002; L. White, study of Head Start mothers, in preparation), while others document processes of constituency building, media imaging, and administration (Davis, 1993; Diamond, 2000; Piven and Cloward, 1977; McCann, 1994; L. Williams, 1995; Edelman, Erlanger, and Lande, 1993; Handler, 1996; Seron, Van Ryzin, Frankel, and Kovath, 2001). But few have examined the process of political change suggested by feminist histories (Minow, 1990; Schneider, 2000): how a cycle initiated through reinterpretation of identities, movement building, and enactment of law might lead to change for the poor. 


\section{Conclusion}

O'Connor has faulted mainstream poverty scholars for allowing themselves to be coopted by the moral framework of conservatives and failing to create an effective alternative understanding of the institutional sources of poverty. Yet many sociolegal scholars who study law and poverty believe they are on a different course. Their research has been motivated by a desire to expose injustice, tell the stories of those oppressed by law, explain why such inequality persists in the welfare state, and thereby create openings for change. Three qualities of recent law and society poverty research suggest the importance of this commitment.

First, for most sociolegal scholars studying poverty the issue is now inequality, not whether the poor have legal experiences that are different from the mainstream. Critical histories of the origins of poverty programs and studies that relate poverty to governance of the morally undeserving - the poor, unmarried mothers, minorities, criminals, and the "underclass" - demonstrate that they are kept isolated and poor in part because of benefits that others derive from law.

Second, researchers are no longer "seeing like a state" (Scott, 1998). Most researchers have rejected the conceptualization of the poor that informs poverty policy and administration and discourages research on race, the causes of poverty, and the labor market. Ethnography, interpretive sociology, and cultural studies have created sightlines for understanding poverty that are different from the state's own. Government-sponsored research, conducted according to a more limited vision, plays an important role in legitimating welfare policy making but must now be read in the context of research by sociolegal scholars and others that speaks directly to the value of such policies from another perspective.

Third, scholars suggest many roles for themselves in bringing about social change. Impact research and detailed case studies that describe processes underlying poverty and injustice speak explicitly to the impulse toward (and faith in) reform. Studies of voices of the oppressed, legal consciousness and resistance, and the poor's political capacity attempt to share the scholar's power to create knowledge with those who have the most direct need for it and the greatest interest in change. The latter are "participatory" in spirit - speaking with the oppressed so that scholars can accurately represent their cause. Some scholars are self-consciously participatory in method as well. Increasingly, scholarship suggests strategies for the activist scholar or the scholar in collaboration with the political allies and subjects of poverty research. Strategies include exploration of genuinely participatory methods for research, debates about more egalitarian and mutually empowering relationships with clients, mapping the opportunities for broader democratic participation in resistance, rights-related movements, and a more inclusive moral discourse.

Scholarship on the relationships between poverty, inequality, and governance still leaves many questions unanswered. Fortunately, sociolegal research suggests places to begin answering the questions that poverty scholars find most compelling. Scholars pursue a better understanding of who controls the market and how law helps or hinders them. Scholars want to know more about how moral identity is formed and changed. Research may eventually suggest how to "democratize" poverty by making the identity of poor persons more visible and less alien to a large proportion of the citizenry in modern, economically developed societies. Further, power and change are often mediated by local social organization and politics, a vast 
uncharted terrain concerning the relationships between local empowerment and laws that guide "devolution," "decentralization," and "marketization."

Finally, there is an emerging consensus that social change through rights will frequently depend on politics. Politics may include the micropolitics of individual resistance, but more significantly will require organizing movements in the public arena. Scholars have suggested that there are openings for political escalation of poverty issues. Movements may successfully deploy new rights, but have often failed in their attempts to do so. Thus, scholars' most ambitious project is understanding how the poor's experiences - including their experiences of subordination and stigmatizing moral identity - can merge with the political interests of other citizens in movements for rights that will enable reconstruction of a more democratic and egalitarian affirmative state.

\section{References}

Abel, R. (1979) "Socializing the legal profession: Can redistributing lawyers' services achieve social justice?" Law and Policy Quarterly 1: 5-52.

Abel, R. (1980) “Taking stock," Law \& Society Review, 14: 429-43.

Alfieri, A. (1991) "Reconstructive poverty law practice: Learning lessons of client narrative," Yale Law Journal 100: 2107-47.

Alfieri, A. (1993) "Impoverished practices," Georgetown Law Journal 81: 2567-663.

Alfieri, A. (2001) "Race prosecutors, race defenders." Georgetown Law Journal 89: 2227-77. Ansley, F. (2002) "Who counts? The case for participatory research,", in F. Munger (ed.), Laboring Below the Line: The New Ethnography of Poverty, Low-wage Work, and Survival in the Global Economy. New York: Russell Sage Foundation, pp. 245-70.

Bennett, S. (1995) "No relief but upon the terms of coming into the house' - controlled spaces, invisible disentitlements, and homelessness in an urban shelter system," Yale Law Journal 104: 2157-211.

Bezdek, B. (2001) "Contractual welfare: Non-accountability and diminished democracy in local government contracts for welfare-to-work services," Fordham Urban Law Journal 28: 1559-608.

Black, D. (1976) The Behavior of Law. New York: Academic Press.

Blumberg, A.S. (1967) "The practice of law as a confidence game: Organizational cooptation of a profession," Law \& Society Review 1(2): 15-39.

Brodkin, E.Z. (1997) "Inside the welfare contract: Discretion and accountability in state welfare administration," Social Service Review 71: 1-33.

Caplovitz, D. (1963) The Poor Pay More: Consumer Practices of Low-Income Families. New York: Free Press.

Carlin, J. (1962) Lawyers on Their Own: A Study of Individual Practitioners in Chicago. New Brunswick, NJ: Rutgers University Press.

Carlin, J. and Howard, J. (1965) "Legal representation and class justice," University of California Law Review 12: 381-437.

Carlin, J., Howard, J., and Messenger, S. (1966) “Civil justice and the poor," Law o Society Review 1(1): 9-90.

Cashin, S.D. (1999) "Federalism, welfare reform, and the minority poor: Accounting for the tyranny of state majorities," Columbia Law Review 99: 552-627.

Chambliss, W. (1964) "A sociological analysis of the law of vagrancy," Social Problems 12: 67-77.

Coombe, R. (1995) "The cultural life of things: Anthropological approaches to law and society conditions of globalization," American University Journal of International Law and Policy 10: 791-835. 
Crenshaw, K. (1988) "Race, reform, and retrenchment: Transformation and legitimation in antidiscrimination law," Harvard Law Review 101: 1331-87.

Danziger, S., et al. (1999) "Barriers to work among welfare recipients," Focus 20: 31-5.

Davis, M. (1993) Brutal Need: Lawyers and the Welfare Rights Movement, 1960-1973. New Haven, CT: Yale University Press.

Diamond, M. (2000) "Community lawyers: Revisiting the old neighborhood," Columbia Human Rights Law Review 32: 67-131.

Diller, M. (2000) "The revolution in welfare administration: Rules, discretion, and entrepreneurial government," New York University Law Review 75: 1121-220.

DuBois, W.E.B. (1899) The Philadelphia Negro. Philadelphia: University of Pennsylvania Press.

Edelman, E.B., Erlanger, H.S., and Lande, J. (1993) "Internal dispute resolution: The transformation of civil rights in the workplace," Law \& Society Review 27: 497-533.

Edin, K. and Lein, L. (1997) Making Ends Meet: How Single Mothers Survive Welfare and Low-Wage Work. New York: Russell Sage Foundation.

Engel, D. (1998) "How does law matter in the constitution of legal consciousness?" in B. Garth and A. Sarat (eds.), How Does Law Matter? Evanston, IL: Northwestern University Press, pp.109-44.

Engel, D. and Munger, F. (forthcoming) Rights of Inclusion: Law and Identity in the Life Stories of Americans with Disabilities. Chicago: University of Chicago Press.

Esping-Anderson, G. (1990) The Three Worlds of Welfare Capitalism. Cambridge, UK: Polity Press.

Esping-Anderson, G. (1999) Social Foundations of Postindustrial Economies. New York: Oxford University Press.

Ewick. P. and Silbey S. (1992) "Conformity, contestation, and resistance: An account of legal consciousness," New England Law Review 26: 731-49.

Ewick, P., Kagan, R., and Sarat, A. (1999) "Legacies of legal realism: Social science, social policy, and the law," in P. Ewick, R. Kagan, and A. Sarat (eds.), Social Science, Social Policy, and the Law. New York: Russell Sage Foundation, pp. 1-38.

Farley, R, Danziger, S., and Holzer, H.J. (2000) Detroit Divided. New York: Russell Sage Foundation.

Felstiner, L.F. (1974) Influences of social organization on dispute processing," Law \& Society Review 9: 63-94.

Felstiner, W., Abel, R., and Sarat, A. (1980) "The emergence and transformation of disputes: Naming, blaming, and claiming," Law \& Society Review 15: 631-55.

Fineman, M.A. (1999) "Cracking the foundational myths: Independence, autonomy, and selfsufficiency," American University Journal of Gender and Social Policy 8: 13-29.

Fraser, N. and Gordon, L. (1994) "A genealogy of dependency: Tracing a keyword of the US welfare state," Signs 19: 309-36. Frazier, E.F. (1939) The Negro Family in the United States. Chicago: University of Chicago
Press.

Freeman, A. (1998) “Antidiscrimnation law from 1954 to 1989: Uncertainty, contradiction, rationalization, denial," in D. Kairys (ed.), The Politics of Law: A Progressive Critique, 3rd edn. New York: Basic Books, pp. 285-311.

Galanter, M (1974) "Why the 'haves' come out ahead: Speculations on the limits of legal change," Law o Society Review 9: 95-160.

Gans, H. (1969) "Culture and class in the study of poverty: An approach to anti-poverty research," in D.P. Moynihan (ed.), On Understanding Poverty: Perspectives From the Social Sciences. New York: Basic Books, pp. 201-28.

Garland, D. (2001) The Culture of Control: Crime and Social Order in Contemporary Society. Chicago: University of Chicago Press.

Garth, B. and Sterling, J. (1998) "From legal realism to law and society: Reshaping law for the last stages of the social activist state," Law \& Society Review 32: 409- 71. 
Gaventa, J. (1980) Power and Powerlessness: Quiescence and Rebellion in an Appalachian Valley. Urbana: University of Illinois Press.

Genovese, E. (1976) Roll, Jordan, Roll. New York: Pantheon Books.

Gilens, M. (1999) Why Americans Hate Welfare: Race, Media, and the Politics of Antipoverty Policy. Chicago: University of Chicago Press.

Gilliom, J. (2001) Overseers of the Poor: Surveillance, Resistance, and the Limits of Privacy. Chicago: University of Chicago Press.

Gooden, S. (1998) “All things not being equal: Differences in caseworkers' support toward black and white welfare clients,"Harvard Journal of African-American Public Policy 4: 23-33.

Gordon, L. (1988a) Heroes of Their Own Lives: The Politics and History of Family Violence, Boston 1880-1960. New York: Penguin.

Gordon, L. (1988b) “What does welfare regulate?" Social Research 55: 611-30.

Gordon, L. (1994) Pitied But Not Entitled: Single Mothers and the History of Welfare, 1890-1935. New York: Academic Press.

Hagan, J. (1994) Crime and Disrepute. Thousand Oaks, CA: Pine Forge Press.

Handler, J.F. (1978) Social Movements and the Legal System: A Theory of Law Reform and Social Change. New York, Academic Press.

Handler, J.F. (1986) The Conditions of Discretion: Autonomy, Community, Bureaucracy. New York: Russell Sage Foundation.

Handler, J.F. (1990) Law and the Search for Community. Philadelphia: The University of Pennsylvania Press.

Handler, J.F. (1992) "Postmodernism, protest, and the new social movements," Law of Society Review 27: 697-731.

Handler, J.F. (1996) Down from Bureaucracy: The Ambiguity of Privatization and Empowerment. Princeton, NJ: Princeton University Press.

Handler, J.F. (2002) "Quiescence: the Scylla and Charybdis of empowerment," in F. Munger (ed.), Laboring Below the Line: The New Ethnography of Poverty, Low-wage Work, and Survival in the Global Economy. New York: Russell Sage Foundation, pp. 271-80.

Handler, J.F. (2003) Social Citizenship and Workfare in the United States and Western Europe: The Paradox of Inclusion. Cambridge, UK: Cambridge University Press.

Handler, J.F. and Hasenfeld, Y. (1991) Moral Construction of Poverty: Welfare Reform in America. Newbury Park, CA: Sage Publications.

Handler, J.F. and Hasenfeld, Y. (1997) We the Poor People: Work, Poverty, and Welfare. New Haven, CT: Yale University Press.

Handler, J.F., Hollingsworth, E.J., and Erlanger, H.S. (1978) Lawyers and the Pursuit of Legal Rights. New York: Academic Press.

Harris, B. (1999) "Representing homeless families: Repeat player implementation strategies" Law o Society Review 33: 911-39.

Hasenfeld, Y. (1983) Human Service Organizations. Englewood Cliffs, NJ: Prentice Hall.

Hay, D. (1975) "Property, authority, and criminal law," in D. Hay, P. Linebaugh, J. G. Rule, E.P. Thompson, and C. Winslow (eds), Albion's Fatal Tree: Crime and Society in Eighteenth-century England. New York: Pantheon Books, pp. 17-63.

Henly, J. (2002) "Informal support networks and the maintenance of low-wage jobs," in F. Munger (ed.), Laboring Below the Line: The New Ethnography of Poverty, Low-wage Work, and Survival in the Global Economy. New York: Russell Sage Foundation, pp. 179-203.

Karst, K. (1989) Belonging in America: Equal Citizenship and the Constitution. New Haven, CT: Yale University Press.

Karst, K. (1997) "The coming crisis of work in constitutional perspective," Cornell Law Review 82: 523-71.

Katz, J. (1978) "Lawyers for the poor in transition: Involvement, reform, and the turnover problem in the legal services program," Law \& Society Review 12: 275-300. 
Katz, M.B. (1986) In the Shadow of the Poorhouse: A Social History of Welfare in America. New York: Basic Books.

Katz, M.B. (1989) The Undeserving Poor: From the War on Poverty to the War on Welfare. New York: Pantheon.

Katz, M.B. (2001) The Price of Citizenship: Redefining the American Welfare State. New York: Metropolitan Books.

Kost, K. and Munger, F. (1996) "Fooling all of the people some of the time: 1990s welfare reform and the exploitation of American values," Virginia Journal of Social Policy \& the Law 4: 3-126.

Ladner, J. (1971) Tomorrow's Tomorrow: The Black Woman. Lincoln: University of Nebraska Press.

Levine, F. and Preston, E. (1970) "Community resource orientation among low income groups," Wisconsin Law Review 1970: 80-113.

Liebow, E. (1967) Tally's Corner: A Study of Negro Streetcorner Men. Boston: Little, Brown.

Lipsky, M. (1984) "Bureaucratic disentitlement in social welfare programs," Social Services Review 58: 3-27.

Lopez, G. (1992) Rebellious Lawyering: One Chicano's Vision of Progressive Law Practice. Boulder, CO: Westview.

Lowi, Theodore (1998) "Think globally, lose locally," Boston Review, online at <http:// bostonreview.net/ BR23.2/lowi.html>

Macaulay, S. (1984) “... Is there any 'there' there" Journal of Law and Policy 6: 149-87.

Macaulay, S. (1986) "Private government," in L. Lipson and S. Wheeler (eds.), Law and the Social Sciences. New York: Russell Sage Foundation, pp. 445-518.

Mahoney, M. (1991) "Legal images of battered women: Redefining the issue of separation," Michigan Law Review 90: 1-94.

Mayhew, L. and Reiss, A.J. (1969) "The social organization of legal contacts," American Sociological Review 34: 309-18.

McCann, M.W. (1994) Rights at Work: Pay Equity Reform and the Politics of Legal Mobilizations. Chicago: University of Chicago Press.

McCann, M. and March, T. (1996) Law and everyday forms of resistance: A socio-political assessment," Studies in Law, Politics, and Society 15: 207-36.

McClain, L. (1996) “'Irresponsible' reproduction,” Hastings Law Journal 47: 339-453.

McCluskey, M. (1999) "Subsidized lives and the ideology of efficiency," American University Journal Gender Social Policy of Law 8: 115-52.

McKinnon, C.A. (1993) "Reflections on law in the everyday life of women," in A. Sarat and T. Kearns (eds.), Law in Everyday Life. Ann Arbor, MI: University of Michigan Press, pp.109-22.

Mead, L. (1986) Beyond Entitlement: The Social Obligations of Citizenship. New York: Free Press.

Mink, G. (1990) "The lady and the tramp: Gender, race, and the origins of the American welfare state," in L. Gordon (ed.), Women, the State, and Welfare. Madison, WI: The University of Wisconsin Press, pp. 92-122.

Minow, M. (1990) Making all the Difference: Inclusion, Exclusion, and American Law. Ithaca, NY: Cornell University Press.

Moore, S.F. (1974) "The semi-autonomous social field as an appropriate subject of study," Law \& Society Review 7: 719-46.

Munger, F. (2002) "Dependency by law: Welfare and identity in the lives of poor women," in A. Sarat, L. Douglas, and M.M. Umphrey (eds.), Lives in the Law. Ann Arbor: University of Michigan Press.

Murphy, R. (1987) The Body Silent. New York: Holt.

Nightingale, C. (2002) "Looking for stories of inner city politics: From the personal to the global," in F. Munger (ed.), Laboring Below the Line: The New Ethnography of Poverty, 
Low-wage Work, and Survival in the Global Economy. New York: Russell Sage Foundation, pp. 111-21.

Noble, C. (1997) Welfare as We Knew It: A Political History of the American Welfare State. New York: Oxford University Press.

Note (1965) "Enforcement of municipal housing codes," Harvard Law Review 78: 801-60.

O'Connor, A. (2001) Poverty Knowledge: Social Science, Social Policy, and the Poor in Twentieth Century U.S. History. Princeton, NJ: Princeton University Press.

O'Gorman, H. (1963) Lawyers and Matrimonial Cases: A Study of Informal Pressures. New York: Free Press.

Pearce, D. (1990) "Welfare is not for women: Why the war on poverty cannot conquer the feminization of poverty," in L. Gordon (ed.), Women, the State, and Welfare. Madison, WI: The University of Wisconsin Press, pp. 265-79.

Piven, F. and Cloward, R. (1971) Regulating the Poor: The Functions of Public Welfare. New York: Pantheon Books.

Piven, F. and Cloward, R. (1977) Poor Peoples' Movements: Why They Succeed, How They Fail. New York, Pantheon Books.

Quadagno, J. (1992) "Social movements and state transformations: Labor unions and racial conflict in the war on poverty," American Sociological Review 57: 616-34.

Quadagno, J. (1994) The Color of Welfare: How Racism Undermined the War on Poverty. New York: Oxford University Press.

Rainwater, L. (1970) "Neutralizing the disinherited: Some psychological aspects of understanding the poor," in V.L. Allen (ed.), Psychological Factors in Poverty. Chicago: Markham Press, pp. 9-27.

Raphael, J. (1996) "Domestic violence and welfare receipt: Toward a new feminist theory of welfare dependency," Harvard Women's Law Journal 19: 201-25.

Reich, C.A. (1964) “The new property," Yale Law Journal 73: 733-87.

Reich, C.A. (1965) "Individual rights and social welfare: Emerging legal issues," Yale Law Journal 74: 1245-57.

Roberts, D. (1997a) Killing the Black Body: Race, Reproduction, and the Meaning of Liberty. New York: Pantheon.

Roberts, D. (1997b) "Spiritual and menial housework," Yale Journal of Law \& Feminism 9: 51-79.

Roberts, D. (1999) "Poverty, race, and new directions in child welfare policy," Washington University Journal of Law and Policy 1: 63-76.

Roberts, D. (2000) "The paradox of silence: Some questions about silence as resistance," Michigan Journal of Race and the Law 5: 927-41.

Rothstein, B. (2001) "Social capital in the social democratic welfare state," Politics and Society 29: 207-41.

Santos, B. de S. (1995) "Three metaphors for a new conception of law: The frontier, the baroque, and the south," Law \& Society Review 29: 569-84.

Sarat, A. (1990) " ‘. . . The law is all over': Power, resistance and the legal consciousness of the welfare poor," Yale Journal of Law of the Humanities 2: 343-79.

Sarat, A. and Felstiner, W. (1995) Divorce Lawyers and their Clients: Power and Meaning in the Legal Process. New York: Oxford University Press.

Sarat, A. and Silbey, S. (1988) "The pull of the policy audience," Law \& Policy 10: 97-165.

Sarat, A. and Simon, J. (2001) "Beyond legal realism?: Cultural analysis, cultural studies, and the situation of legal scholarship," Yale Journal of Law \& Humanities 13: 3-32.

Schneider, E. (1986) "The dialectic of rights and politics: Perspectives from the women's movement," New York University Law Review 61: 589-652.

Schneider, E. (2000) Battered Women and Feminist Lawmaking. New. Haven, CT: Yale University Press. 
Scott, J. (1998) Seeing Like a State: How Certain Schemes to Improve the Human Condition Have Failed. New Haven, CT: Yale University Press.

Seron, C., Van Ryzin, G., Frankel, M., and Kovath, J. (2001) "The impact of legal counsel on outcomes for poor tenants in New York city's housing court: Results of a randomized experiment," Law \& Society Review 35: 419-34.

Silbey, S. and Sarat, A. (1987) "Critical traditions in law and society research," Law \& Society Review 21: 165-74.

Simon, J. (1992) “'The long walk home' to politics," Law or Society Review 26: 923-41.

Simon, J. (1997) “Governing through crime,” in L. Friedman and G. Fisher (eds.), The Crime Conundrum: Essays on Criminal Justice. Bridgeport, CT: Westview, pp. 171-89.

Simon, J. (1999) "Law after society," Law and Social Inquiry 24: 143-94.

Simon, W. (1983) "Legality, bureaucracy, and class in the welfare system," Yale Law Journal 92: 1198-269.

Simon, W. (1996) "The dark secret of community based lawyering: A comment on poverty law scholarship in the post-modern, post-Reagan era," University of Miami Law Review 48: 1099-114.

Skocpol, T. (1992) Protecting Soldiers and Mothers: The Political Origins of Social Policy in the United States. Cambridge, MA: The Belnap Press of Harvard University.

Smith, R. (1988) "Political jurisprudence: The new institutionalism and the future of public law," American Political Science Review 82: 89-108.

Soule, S.A. and Zylan, Y. (1997) "Runaway train? The diffusion of state-level reform in ADC/ AFDC requirements, 1950-1967," American Journal of Sociology 103: 733-62.

Soss, J. (1999) "Lessons of welfare policy design, political learning, and political action." American Political Science Review 93: 363-80.

Stack, C. (1976) All Our Kin: Strategies for Survival in a Black Community. New York: Basic Books.

Sterett, S. (1997) "Serving the states: Constitutionalism and social spending $1860 \mathrm{~s}-1920$ s," Law and Social Inquiry 22: 311-56.

Suchman, M. and Edelman, L. (1996) "Legal rational myths: The new institutionalism and the law and society tradition," Law and Social Inquiry 21: 903-41.

Thompson, E.P. (1975) Whigs and Hunters: The Origins of the Black Act. New York: Pantheon.

Trubek, L. (1994) "Lawyering for poor people: Revisionist scholarship and practice," Miami Law Review 48: 983-97.

Wald, P. (1965) Law and Poverty. Washington, DC: US GPO.

White, J.A. (2000) Democracy, Justice and the Welfare State: Reconstructing Public Care. University Park, PA: The Pennsylvania State University.

White, L. (1988) "To learn and teach: Lessons from Driefontein on lawyering and power," Wisconsin Law Review 1988: 699-769.

White, L. (1990) "Subordination, rhetorical survival skills, and Sunday shoes: Notes on the hearing of Mrs. G.," Buffalo Law Review 38: 1-58.

White, L. (1993) "No exit: Rethinking welfare dependency from a different ground," Georgetown Law Journal 81: 1961-2002.

White, L. (1998) "Facing south: Lawyering for poor communities in the twenty-first century," Fordham Urban Law Review 25: 813-29.

White, L. (2002) "Care at work," in F. Munger (ed.), Laboring Below the Line: The New Ethnography of Poverty, Low-wage Work, and Survival in the Global Economy. New York: Russell Sage Foundation, pp. 213-44.

Williams, J. (1999) "Implementing antiessentialism: How gender wars turn into race and class conflict," Harvard BlackLetter Law Journal 15: 41-81.

Williams, L.A. (1992) "The ideology of division: Behavior modification welfare reform proposals," Yale Law Journal 102: 719-46. 
Williams, L.A. (1995) "Race, rat bites, and unfit mothers: How media discourse informs welfare legislation debate," Fordham Urban Law Journal 22: 1159-96.

Williams, P. (1991) The Alchemy of Race and Rights. Cambridge, MA: Harvard University Press.

Wright, E.O. (1994) Interrogating Inequality: Essays on Class Analysis, Socialism and Marxism. London: Verso.

Wuthnow, R. (1996) Poor Richard's Principle: Recovering the American Dream Through the Moral Dimensions of Work, Business, and Money. Princeton, NJ: Princeton University Press. 